\title{
Pelatihan Pembuatan Sabun Cair Cuci Tangan di BUMDES Sei Rampah, Serdang Bedagai, Sumatera Utara
}

\author{
Bayu Eko Prasetyo*1, Sri Yuliasmi², Henny Sri Wahyuni ${ }^{3}$, Lia Laila ${ }^{4}$ \\ 1,4Departemen Teknologi Farmasi, Fakultas Farmasi, Universitas Sumatera Utara, Medan, 20155 \\ 2,3Departemen Kimia Farmasi, Fakultas Farmasi, Universitas Sumatera Utara, Medan, 20155 \\ *e-mail: bayu@usu.ac.id
}

\begin{abstract}
Covid-19 pandemic that still worrying and also very low of awareness of Indonesian people to follow the health protocol; stimulate the community service team to give some contributions in order to prevent the Covid-19 transmission. Village-owned enterprises (BUMDes) at Sei Rampah district was chosen as the partner due to the high economical activity and the location is near to Medan city. Workshop on liquid hand soap which is one of the important procedures in viral transmission prevention was done by having a direct gathering with limited number of participants and using a strict health protocol. Preparation of learning video, workshop module and direct demonstration in front of participants were conducted in order to effectively transfer the technology though in limited act. The community service activity was done without any obstacles and could increase the knowledge and awareness in health protocol application in order to prevent the Covid-19 transmission; and also the liquid hand soap produced can be developed as business product for the villageowned enterprises.
\end{abstract}

Keywords: Covid-19, liquid hand soap, Village-Owned Enterprises (BUMDes), community service

\begin{abstract}
Abstrak
Kondisi pandemi Covid-19yang masih mengkhawatirkan serta ditambah pula kesadaran masyarakat Indonesia untuk mengikuti protokol kesehatan yang masih sangat rendah, menggunggah tim pengabdian untuk turut memberikan kontribusi dalam mencegah penyebaran Covid 19. Badan Usaha Milik Desa (BUMDes) di kecamatan Sei Rampah dipilih sebagai mitra pengabdian karena aktivitas perekonomian yang padat dan lokasi yang dekat dengan Kota Medan. Pelatihan pembuatan sabun cair cuci tangan yang merupakan salah satu prosedur yang sangat penting dalam mencegah penularan virus dilakukan dengan cara temu muka dengan jumlah peserta terbatas dan penggunaan protokol kesehatan yang ketat. Pembuatan video pembelajaran, modul pelatihan dan demonstrasi langsung di depan peserta dilakukan sehingga diharapkan transfer teknologi yang dilakukan dapat berjalan dengan efektif walau dilakukan dengan penuh keterbatasan. Pengabdian masyarakat yang telah dilakukan berjalan dengan lancar dan diharapkan dapat menambah pengetahuan, serta meningkatkan kesadaran untuk mengikuti protokol kesehatan dalam usaha mencegah penularan virus Covid 19 dan diharapkan sabun cuci tangan yang dihasilkan dapat terus dikembangkan menjadi produk usaha BUMDes tersebut.
\end{abstract}

Kata kunci: Covid-19, Sabun cair cuci tangan, Badan Usaha Milik Desa (BUMDes), pengabdian masyarakat

\section{PENDAHULUAN}

Wabah dan penularan Virus Corona (Covid-19) yang telah menggemparkan dunia di awal tahun 2020 ternyata belum diketahui dengan pasti kapan akan benar benar berakhir. Badan Kesehatan Dunia (WHO) telah menyatakan virus corona sebagai pandemi mulai bulan Maret 2020, yang artinya bahwa virus corona dinyatakan dapat menyebar dengan cepat dan dapat berpindah dari satu manusia ke manusia lainnya. Berbagai negara-negara di Dunia segera melakukan berbagai kebijakan dan antisipasi untuk menangani masalah ini. Menindak lanjuti hal ini, pemerintah Indonesia sebenarnya telah menyatakan wabah ini sebagai wabah nasional non alam dan mengambil berbagai langkah dan kebijakan untuk mengatasi permasalahan ini, baik di tingkat pusat maupun daerah, namun hasilnya masih dirasakan belum maksimal (Zahrotunnimah, 2020).

Selain permasalahan kebijakan pemerintah, pengetahuan dan kesadaran masyarakat yang sangat rendah tentang bahaya Covid 19 juga menjadi tantangan tersendiri bagi bangsa Indonesia 
untuk dapat segera terlepas dari cengkeraman wabah ini. Himbauan-himbauan untuk mematuhi protokol kesehatan yang disampaikan pemerintah ternyata masih tidak dilaksanakan dengan baik oleh masyarakat Indonesia (Buana, 2020). Padahal, kesadaran masyarakat untuk mematuhi protokol kesehatan ini merupakan salah satu kunci keberhasilan penanggulangan Covid-19 (Prasetyo, 2020).

Perilaku memiliki hubungan yang sangat erat dengan kesehatan, dimana perilaku menjaga kesehatan yang baik akan membantu seseorang tetap sehat. Salah satu perilaku yang sangat efektif dalam mencegah penularan penyakit adalah dengan membiasakan perilaku cuci tangan dengan menggunakan sabun dan air mengalir (Risnawaty, 2016). Mencuci tangan dengan menggunakan sabun dan air mengalir terbukti dapat menurunkan jumlah kuman pada tangan secara signifikan, dibandingkan dengan tanpa menggunakan sabun (Desiyanto, 2013). Oleh karenanya, salah satu himbauan Badan Kesehatan Dunia (WHO) adalah membiasakan untuk membersihkan tangan secara teratur dengan menggunakan gel yang mengandung alkohol (hand sanitizer) atau dengan cara mencuci tangan secara rutin dengan menggunakan sabun dan air yang mengalir (WHO, 2020).

Berbagai jenis sabun cuci tangan telah diteliti dan diuji efektifitasnya. Pembuatan sabun cair cuci tangan dengan menggunakan berbagai ekstrak tanaman yang telah diketahui memiliki efek antibakteri juga telah banyak dilakukan, seperti penggunaan ekstrak etanol rumput laut (Akib, 2019), ekstrak etanol daun kemangi (Nurlina, 2013) atau ekstrak etanol daun seledri (Ardina, 2017). Efek anti bakteri dari ekstrak tanaman-tanaman tersebut sangat membantu meningkatkan keefektifan sabun dalam mencegah dan melindungi penularan penyakit-penyakit berbahaya.

Berdasarkan latar belakang tersebut, tim pengabdian merasa terpanggil untuk dapat berkontribusi membantu pemerintah dalam memberikan pengetahuan kepada masyarakat mengenai pentingnya rutinitas melakukan cuci tangan dengan menggunakan sabun dan air mengalir, khususnya mitra pada pengabdian ini yaitu Pengurus BUMDes Kecamatan Sei rampah, Kabupaten Serdang Bedagai, Sumatera Utara. Melalui kegiatan ini, diharapkan kesadaran masyarakat mengenai pentingnya cuci tangan dengan menggunakan sabun menjadi meningkat sebagai salah satu langkah yang efektif dalam memutus mata rantai penyebaran Virus Covid-19. Pelatihan pembuatan sabun cuci tangan cair juga dilakukan sebagai usaha transfer teknologi kepada mitra pengabdian sehingga dapat dipraktekkan secara langsung dalam penggunaan sehari-hari, bahkan dapat dikembangkan menjadi bernilai ekonomi, sebagai produk usaha bagi BUMDes.

\section{METODE}

Pengabdian masyarakat dilakukan dalam beberapa tahapan pelaksanaan kegiatan dengan tetap menjaga protokol kesehatan, antara lain:

1. Silaturahmi dan sosialisasi terhadap pengurus BUMDes Bersama Kecamatan Sei Rampah dan juga Bapak Camat Sei Rampah dalam rangka memperkenalkan tim pengabdian, serta memaparkan tujuan serta program pengabdian yang akan dilaksanakan dengan melibatkan mitra.

2. Pengumpulan data dan studi literatur terkait dengan jenis sabun cair yang dibuat, metode pembuatan, dan perancangan kemasan yang menarik dan ekonomis sehingga peserta pelatihan memiliki ketertarikan terhadap produk yang dibuat dan bersemangat untuk mengembangkan produk sabun cair ini di masa yang akan datang sebagai produk usaha mereka.

3. Pembuatan modul, video pembuatan dan produk sabun cair yang telah selesai dikemas untuk dibagikan kepada para peserta pada saat pelaksanaan pengabdian masyarakat untuk memaksimalkan pelatihan. Strategi penggunaan video pembelajaran dan modul dilakukan sebagai solusi bagi memudahkan peserta dalam memahami materi yang diberikan karena keterbatasan interaksi yang dapat dilakukan antara tim pengabdian dan 
peserta selama masa pandemi. Pembuatan formula sabun cair cuci tangan dilakukan berdasarkan modifikasi metode dari Kusumayanti, dkk (2018).

4. Penyampaian materi dengan strategi ceramah untuk memberikan informasi yang benar tentang bahaya Covid-19 dan bagaimana cara memutus mata rantai penyebaran virus tersebut. Pelatihan pembuatan sabun cair dilakukan dengan strategi demo oleh tim pengabdian didepan para peserta pelatihan. Sabun cair cuci tangan ini digunakan sebagai salah satu solusi dalam menekan penyebaran Virus Covid-19 dan membantu memotivasi pengurus BUMDes dan masyarakat agar dapat terus mengembangkan sediaan ini untuk dijual ke pasaran sehingga dapat menjadi salah satu produk unggulan yang dapat dikembangkan oleh BUMDes Bersama Kecamatan Sei Rampah.

Evaluasi terhadap produk sabun cair yang dihasilkan serta pelaksanaan kegiatan pengabdian masyarakat dilakukan dengan metode kuisioner penilaian. Penyebaran kuisioner penilaian dilakukan secara langsung terhadap peserta pelatihan untuk menilai tingkat kepuasan peserta pelatihan terhadap pelaksanaan pengabdian yang dilakukan dan untuk mendapatkan saran dan masukan bagi perbaikan kedepannya. Penilaian yang dilakukan melibatkan 30 orang peserta pelatihan.

\section{HASIL DAN PEMBAHASAN}

Pelaksanaan kegiatan pengabdian yang dilakukan berjalan dengan lancar baik dari proses pertemuan awal dengan para pengurus BUMDes dan Bapak Camat Kecamatan Sei Rampah dalam rangka perkenalan tim dengan mitra pengabdian, persiapan yang dilakukan sebelum pelaksanaan pengabdian hingga waktu dilaksanakannya proses pengabdian masyarakat berupa penyuluhan dan demo pembuatan sediaan sabun cair cuci tangan oleh tim. Semua kegiatan yang dilakukan berjalan sebagaimana yang telah diagendakan tanpa mengalami kendala yang berarti. Pelaksanaan seluruh kegiatan dilakukan dengan tetap menjaga protokol kesehatan secara ketat seperti penyediaan sarana cuci tangan bagi para peserta, penyediaan hand sanitizer, penggunaan masker bagi seluruh peserta pelatihan serta tetap menjaga jarak saat berinteraksi dengan peserta selama pelaksanaan pengabdian.

Pelaksanaan pengabdian dimulai dengan pemberian penyuluhan materi terkait bahaya Covid 19 dan bagaimana langkah-langkah mencegah penularan Covid 19. Kegiatan dilanjutkan dengan penjelasan secara singkat mengenai tatacara pembuatan sediaan sabun cair cuci tangan. Pelaksanaan demo pembuatan sediaan sabun cair cuci tangan oleh tim pengabdian masyarakat juga dilakukan baik secara langsung maupun dengan pemutaran video yang telah disiapkan sebelumnya. Setiap peserta pelatihan juga mendapatkan modul yang berisi materi penyuluhan terkait Covid-19 dan juga prosedur pembuatan sediaan sabun cair mulai dari penyediaan bahan yang digunakan hingga langkah-langkah pembuatan sehingga dapat memudahkan peserta untuk membuat sediaan tersebut secara mandiri di masa yang akan datang.

Dalam perjalanannya, para peserta sangat antusias mendengarkan penjelasan dan arahan dari tim pengabdian yang juga dibantu oleh beberapa mahasiswa yang turut terlibat dalam pelaksanaan pengabdian. Diskusi yang dilakukan setelah pemberian materi juga berlangsung dengan baik dengan banyaknya pertanyaan yang dilontarkan oleh para peserta. Dokumentasi kegiatan pengabdian masyarakat dan produk sabun cuci tangan yang dihasilkan dapat dilihat pada gambar 1 . 


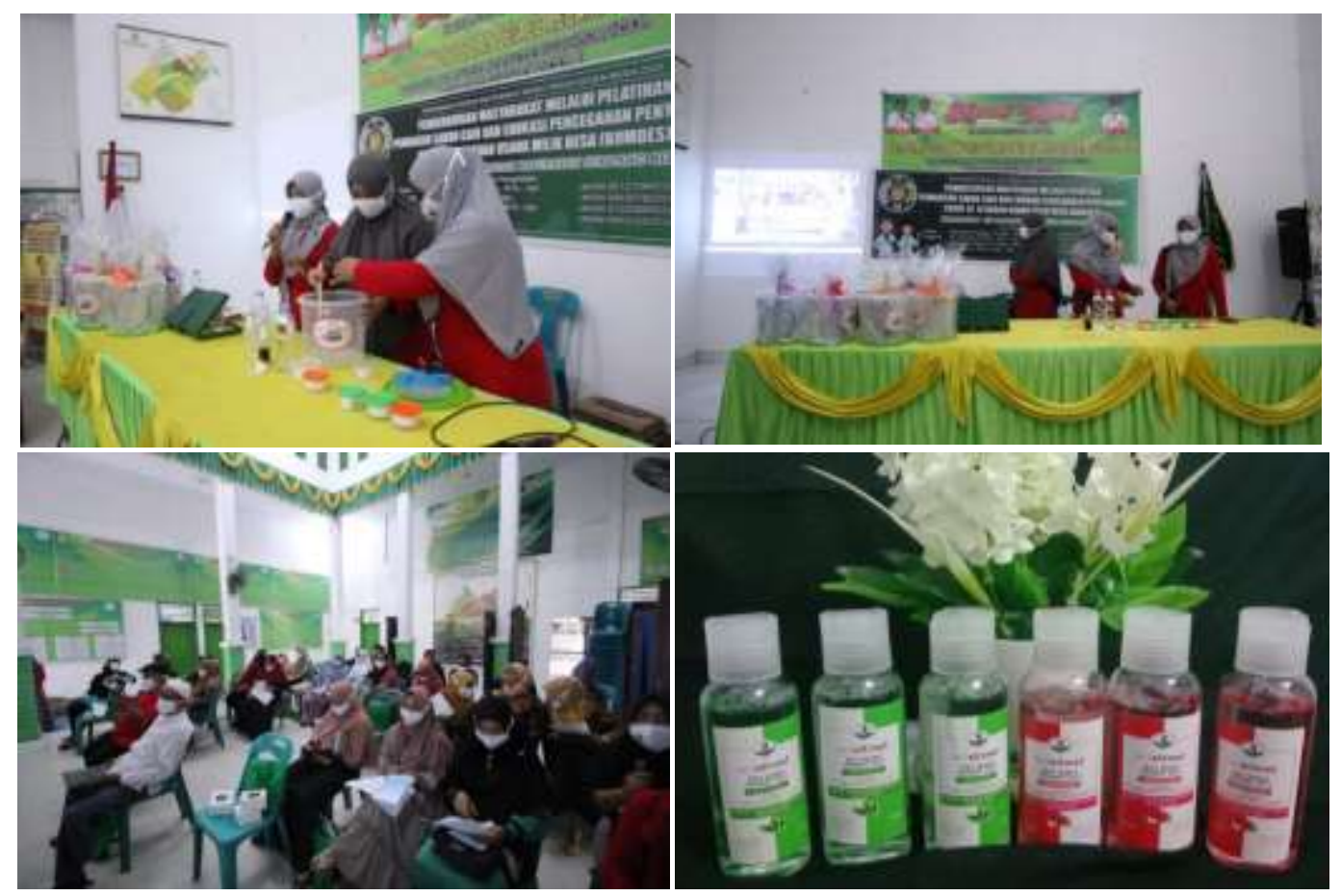

Gambar 1. Dokumentasi kegiatan dan produk pengabdian masyarakat yang dihasilkan

Penilaian terhadap produk sabun cair cuci tangan yang dihasilkan dari pengabdian masyarakat ini dapat diketahui dari hasil penyebaran kuisioner terhadap para peserta pelatihan. Para peserta dengan sangat antusias mengisi kuisioner yang diberikan dan hasil penilaiannya dapat dilihat pada tabel 1. Selain itu, sebagai evaluasi terhadap pelaksanaan kegiatan pengabdian masyarakat yang dilakukan, kuisioner penilaian kegiatan juga dibagikan kepada para peserta dan hasilnya dapat dilihat pada tabel 2.

Tabel 1. Penilaian peserta terhadap produk sabun cair cuci tangan yang dihasilkan

\begin{tabular}{lccccc}
\hline \multirow{2}{*}{ Kategori } & \multicolumn{5}{c}{ Penilaian Peserta (\%) } \\
\cline { 2 - 6 } & 1 & 2 & 3 & 4 & 5 \\
\hline Kemasan & - & - & 3.33 & 63.33 & 23.33 \\
Warna & - & - & 23.33 & 40 & 36.66 \\
Tekstur & - & 3.33 & 26.66 & 60 & 10 \\
Aroma & - & 6.66 & 33.33 & 36.66 & 23.33 \\
Mudah dituang & - & 6.66 & 13.33 & 60 & 10 \\
\hline Keterangan: & & & & & \\
1 & $=$ Tidak Suka & & & & \\
2 & $=$ Kurang suka \\
3 & $=$ Netral & & & & \\
4 & $=$ Suka \\
5 & $=$ Sangat Suka & & & &
\end{tabular}

Pada tabel 1 diperoleh data bahwa secara umum, para peserta merasa puas dengan sediaan sabun cair cuci tangan yang dibuat, dimana dari 5 kriteria yang ditanyakan, lebih dari 70 $\%$ responden menyatakan suka bahkan sangat suka terhadap kemasan, warna, tekstur, aroma dan kemudahan untuk dituang. Hanya beberapa peserta yang menyatakan kurang suka terhadap aroma dan kemudahan menuang sediaan sabun cair tersebut. Bahan pewangi sebagai aroma yang digunakan sebagai contoh pada pengabdian kali ini adalah aroma green tea dan sweet apple sehingga mungkin saja ada peserta yang kurang menyukainya. Namun, pada pelaksanaan pengabdian juga telah disampaikan kepada para peserta bahwa dalam mengembangkan produk 
sabun cair cuci tangan ini, para peserta nantinya bebas menggunakan pewangi apa saja sesuai dengan keinginannya, bahkan para peserta dapat mengatur tingkat kekentalan sabun cair yang dihasilkan dengan melakukan sedikit perubahan pada komposisi bahan yang digunakan sehingga sesuai dengan keinginan.

Tabel 2. Evaluasi terhadap pelaksanaan pengabdian masyarakat

\begin{tabular}{|c|c|c|c|c|c|}
\hline \multirow{2}{*}{ No } & \multirow{2}{*}{ Pernyataan } & \multicolumn{4}{|c|}{ Penilaian peserta (\%) } \\
\hline & & SS & $\mathrm{S}$ & TS & STS \\
\hline 1 & $\begin{array}{l}\text { Saya merasa puas dengan kegiatan pengabdian } \\
\text { masyarakat yang diselenggarakan }\end{array}$ & 46.66 & 53.33 & - & - \\
\hline 2 & $\begin{array}{l}\text { Materi yang disampaikan oleh anggota kegiatan mudah } \\
\text { dipahami }\end{array}$ & 40 & 56.66 & 3.33 & - \\
\hline 3 & $\begin{array}{l}\text { Kegiatan pengabdian masyarakat yang diselenggarakan } \\
\text { sesuai dengan harapan saya }\end{array}$ & 46.66 & 53.33 & - & - \\
\hline 4 & $\begin{array}{l}\text { Personil/anggota yang terlibat dalam kegiatan } \\
\text { pengabdian masyarakat memberikan pelayanan sesuai } \\
\text { dengan kebutuhan saya }\end{array}$ & 33.33 & 63.33 & 3.33 & - \\
\hline 5 & $\begin{array}{l}\text { Pelatihan yang dilakukan dapat meningkatkan } \\
\text { pengetahuan dan keterampilan peserta }\end{array}$ & 56.66 & 43.33 & - & - \\
\hline 6 & Waktu yang tersedia untuk pelatihan mencukupi & 30 & 60 & 6.66 & 3.33 \\
\hline 7 & $\begin{array}{l}\text { Narasumber menyajikan materi dengan jelas dan } \\
\text { berurutan }\end{array}$ & 33.33 & 63.33 & 3.33 & - \\
\hline 8 & Proses pembuatan sabun cair mudah dilakukan & 30 & 70 & - & - \\
\hline 9 & $\begin{array}{l}\text { Peralatan yang disediakan untuk pelatihan cukup } \\
\text { memadai }\end{array}$ & 30 & 70 & - & - \\
\hline 10 & $\begin{array}{l}\text { Topik pelatihan kegiatan pengabdian masyarakat } \\
\text { menarik untuk diikuti }\end{array}$ & 40 & 60 & - & - \\
\hline 11 & $\begin{array}{l}\text { Jika kegiatan ini diselenggarakan kembali, saya } \\
\text { bersedia untuk berpartisipasi }\end{array}$ & 43.33 & 50 & 6.66 & - \\
\hline
\end{tabular}

Keterangan:

SS = Sangat Setuju

$\mathrm{S} \quad=$ Setuju

TS $\quad=$ Tidak Setuju

STS = Sangat Tidak Setuju

Berdasarkan tabel 2, terlihat secara umum, peserta pelatihan merasa puas terhadap pelatihan yang dilakukan, hampir semua pertanyaan yang diajukan direspon oleh peserta dengan pernyataan setuju bahkan sangat setuju dengan persentase yang sangat baik. Beberapa pernyataan yang masih perlu diperhatikan diantaranya adalah materi yang masih sedikit sulit dipahami oeleh beberapa peserta dan waktu yang dirasakan peserta sangat sedikit sehingga perlu ditambah lebih lama. Hal ini tentu dapat dipahami dikarenakan adanya pembatasan waktu interaksi dengan peserta karena pelaksanaan pengabdian masyarakat dilakukan di masa pandemi Covid-19 seperti saat ini. Penyertaan modul dan video pembelajaran diharapkan dapat menjadi solusi permasalahan ini karena peserta dapat berulang-ulang membaca modul dan menonton video yang diberikan sehingga dapat dipelajari lebih lanjut secara mandiri. Satu hal yang sangat menggembirakan bagi tim pengabdian adalah antusiame yang tinggi dalam pelaksanaan pengabdian dimana 93,33 \% peserta menyatakan ingin ikut kembali pada kegiatan pengabdian masyarakat yang diadakan di masa yang akan datang. 
Pelatihan dalam pengembangan produk, baik produk makanan atau kesehatan bagi komunitas atau perkumpulan masyarakat sangatlah penting dan menarik untuk terus dikembangkan. Banyak pelatihan yang dilakukan dalam rangka pelaksanaan pengabdian masyarakat yang bertujuan untuk membantu memotivasi atau sebagai transfer pengetahuan untuk diaplikasikan bagi masyarakat sehingga dapat meningkatkan aktivitas positif anggota komunitas, dan juga pengembangan ekonomi. Pelatihan yang pernah dilakukan antara lain pembuatan Virgin Coconut Oil (VCO) pada ibu ibu PKK di Nagari Sikucur Barat, Sumatera Barat yang dapat meningkatkan nilai ekonomi dari kelapa di daerah tersebut (Yermadona, 2019). Pelatihan pembuatan dan produksi pangan produk bawang goreng yang baik juga pernah dilakukan terhadap ibu-ibu yang aktif dalam industri rumah tangga di daerah Pekanbaru sehingga dapat membantu mereka dalam meningkatkan kualitas bawang goreng yang diproduksi (Asih, 2019). Pelatihan pembuatan sabun cuci tangan yang telah dilakukan juga diharapkan selain membantu dalam memutus mata rantai penyebaran virus Covid-19 dapat pula dijadikan sebagai produk usaha mitra pengabdian.

\section{KESIMPULAN} berikut:

Dari hasil pengabdian masyarakat yang telah dilakukan dapat disimpulkan sebagai

1. Pengurus BUMDes dan masyarakat sekitar sangat antusias mengikuti pelatihan dan mendapatkan pemahaman mengenai bahaya Covid-19 dan menambah wawasan tentang langkah-langkah mencegah penyebaran virus tersebut, khususnya meningkatkan kesadaran pentingnya sering melakukan cuci tangan dengan menggunakan sabun dan air mengalir.

2. Pengurus BUMDes dan masyarakat sekitar sebagai mitra pengabdian mendapatkan ilmu pengetahuan tentang tatacara pembuatan sabun cair cuci tangan melalui proses pengabdian masyarakat yang telah dilaksanakan yang jika dikembangkan akan memiliki prospek yang sangat baik sebagai produk usaha bagi BUMDes tersebut.

\section{UCAPAN TERIMA KASIH}

Penulis mengucapkan terima kasih kepada mitra pengabdian yaitu pengurus dan anggota BUMDes Bersama Kecamatan Sei Rampah serta Camat kecamatan Sei Rampah beserta jajarannya yang telah memberikan respon positif, bantuan dan kerjasamanya sehingga kegiatan pengabdian masyarakat dapat terlaksana dengan baik dan lancar. Penulis juga mengucapkan terima kasih kepada Rektor Universitas Sumatera Utara atas bantuan pembiayaan yang diberikan melalui pendanaan NON PNBP Universitas Sumatera Utara sesuai dengan Surat Perjanjian Penugasan Pelaksanaan Pengabdian kepada Masyarakat Program Mono Tahun Dosen Muda Tahun Anggaran 2020.

\section{DAFTAR PUSTAKA}

Angka Kuman. KESMAS. 2013: 75-82. http://dx.doi.org/10.12928/kesmas.v7i2.1041

Ardina, Suprianto. (2017). Formulasi Sabun Cair Antiseptik Ekstrak Etanol Daun Seledri (Apium $\begin{array}{lllll}\text { graviolens } & \text { L.). Jurnal Dunia }\end{array}$ https://doi.org/10.33085/dunia\%20farmasi.v2il.4393

Asih, E. R., \& Arsil, Y. 2019. Penerapan Cara Produksi Pangan Yang Baik Pada IRT Bawang Goreng $\begin{array}{lllll}\text { Kota Pekan } \quad \text { Baru. Jurnal DINAMISIA. } & \text { 3(2): } 21-227 .\end{array}$ https://doi.org/10.31849/dinamisia.v3i2.3229

Buana, D. R. (2020). Analisis Perilaku Masyarakat Indonesia dalam Menghadapi Pandemi Virus Corona (Covid-19) dan Kiat Menjaga Kesejahteraan Jiwa. SALAM: Jurnal Sosial dan Budaya Syar-i, 7(3): https://doi.org/10.15408/sjsbs.v7i3.15082 
Desiyanto, F.A., \& Sitti N. D. (2013). Efektifitas mencuci Tangan Menggunakan Cairan Pembersih Tangan Antiseptik (Hand Sanitizer) Terhadap Jumlah

Kusumayanti, H., Paramita, V., Wahyunimgsih, Amalia, R., Siregar, V.D., Pudistuningtyas, N. (2018). Pelatihan dan Praktek Pembuatan Sabun Cuci Tangan Cair di PKK Tembalang Pesona asri. Gema Teknologi. 2018(20): 24-25. 10.14710/gt.v20i1.21079

Nurlina, Attamimi, F., Rosvina, Tomagola, I. (2013). Formulasi Sabun Cair Pencuci Tangan Yang Mengandung Ekstrak Daun Kemangi (Ocimum basilicum L.). As-Syifaa, 5(2):119-127

Prasetyo, A. (2020). Kesadaran Masyarakat, Kunci Penanggulangan Covid-19. Diakses tanggal 29 September 2020. https://mediaindonesia.com/read/detail/297716-kesadaran-masyarakatkunci-penanggulangan-covid-19

Risnawaty, G. (2016). Faktor Determinan Perilaku Cuci Tangan Pakai Sabun (CTPS) Pada Masyarakat di Tanah Kalikedinding. Jurnal Promkes. 4(1):70-81.10.20473/jpk.V4.I1.2016.7081

WHO (2020). WHO Save Lives: Clean Your Hands In The Context Of Covid-19. Diakses tanggal 29 September 2020. https://www.who.int/infection-prevention/campaigns/cleanhands/WHO_HH-Community-Campaign_finalv3.pdf?ua=1

Yermadona, H., Earnestly, F., Afrijon., Suryani, S \& Firdaus. 2019. Pemberdayaan Ibu-Ibu PKK Nagari Sikucur Barat Melalui Produksi Virgin Coconut Oil (VCO). Jurnal DINAMISIA. 3 (Special Issue Juni 2019): 171-180. https://doi.org/10.31849/dinamisia.v3i0.2918

Zahrotunnimah (2020). Langkah Taktis Pemerintah Daerah Dalam Pencegahan Penyebaran Virus Corona Covid-19 di Indonesia. Jurnal Sosial dan Budaya Syar'i. 7(3): 247-260. 